\title{
Correction to: Safety pharmacology of acute LSD administration in healthy subjects
}

\author{
Friederike Holze ${ }^{1,2} \cdot$ Toya V. Caluori $^{1,2} \cdot$ Patrick Vizeli $^{1,2} \cdot$ Matthias E. Liechti ${ }^{1,2}$
}

Published online: 27 September 2021

○) Springer-Verlag GmbH Germany, part of Springer Nature 2021

\section{Correction to: Psychopharmacology https://doi.org/10.1007/s00213-021-05978-6}

In the published article, the column headers of Table 1 are incorrectly presented.

The original article has been corrected.

Publisher's note Springer Nature remains neutral with regard to jurisdictional claims in published maps and institutional affiliations.

The original article can be found online at https://doi.org/10.1007/ s00213-021-05978-6.

Matthias E. Liechti matthias.liechti@usb.ch

1 Division of Clinical Pharmacology and Toxicology, Department of Biomedicine and Department of Clinical Research, University Hospital Basel and University of Basel, Schanzenstrasse 55, CH-4056 Basel, Switzerland

2 Department of Pharmaceutical Sciences, University of Basel, Basel, Switzerland 